\title{
Opportunistic pathogenic fungi isolated from feces of feral pigeons in Mafikeng, North West Province of South Africa
}

\author{
Michelo Syakalima, Tsepo Ramatla and Ngoma Lubanza \\ Department of Animal Health, School of Agriculture, Faculty of Natural and Agricultural Sciences, Mafikeng Campus, \\ North-West University, Private Bag X2046, Mmabatho 2735, South Africa. \\ Corresponding author: Michelo Syakalima, e-mail: michsan65@gmail.com \\ Co-authors: TR: ra21205450@gmail.com, NL: ngomalubanza@gmail.com \\ Received: 21-02-2019, Accepted: 07-06-2019, Published online: 18-07-2019
}

doi: 10.14202/vetworld.2019.1066-1069 How to cite this article: Syakalima M, Ramatla T, Lubanza N (2019) Opportunistic pathogenic fungi isolated from feces of feral pigeons in Mafikeng, North West Province of South Africa, Veterinary World, 12(7): 1066-1069.

\begin{abstract}
Background and Aim: Pigeon feces are increasingly being implicated in the spread of bacterial pathogens such as Escherichia coli, Campylobacter, Salmonella, Listeria, and Chlamydia. Fungi are rarely investigated except for Cryptococcus that has emerged as an important pathogen in old people and immunosuppressed patients. This study investigated fungi in pigeon feces collected from Mafikeng, the North West Province of South Africa.

Materials and Methods: Freshly dropped feces were collected and enriched in phosphate-buffered saline overnight at $48^{\circ} \mathrm{C}$ and then subcultured on Sabouraud's dextrose agar and incubated at $48^{\circ} \mathrm{C}$ for 2 weeks observing any fungal growth from day 2. The growths were picked up, DNA extracted, and polymerase chain reaction was done using the internal transcribed spacer primers.

Results: Fungi isolated included: Aspergillus (Aspergillus tubingensis), Cryptococcus (Cryptococcus albidus and Cryptococcus randhawai), Fusarium spp., and Rhodotorula (Rhodotorula mucilaginosa and Rhodotorula kratochvilovae). Most of these isolates are known opportunistic pathogens and have been isolated in clinical conditions elsewhere. Other isolates such as Graphium dubautiae, Myrmecridium schulzeri, Naganishia albida, Paecilomyces lilacinus, and Zygopleurage zygospora were not found to be of any human health significance.
\end{abstract}

Conclusion: We, therefore, concluded that the presence of these opportunistic pathogens is a significant human health risk, especially in the face of the HIV/AIDS pandemic that results in immunosuppression.

Keywords: chain reaction, fungi, opportunistic pathogens, pigeon feces, polymerase.

\section{Introduction}

Feral pigeons frequently reside in close proximity to human habitats consequently dropping feces and littering the environment that they share with humans. Their presence in the human environment and the litter they produce is increasingly being recognized as a source of significant human pathogens responsible for some very important infections [1]. Pathogens such as Escherichia coli, Campylobacter, Salmonella, Listeria, Chlamydia, and Cryptococcus have been isolated from these pigeons and are known to be spread to humans through the air, food, or drinking water contaminated by pigeon droppings, nesting materials, or even dead carcasses [2]. Pigeons may also carry mites, which are vectors of pathogens that may find their way to humans and other animals.

Of the pathogens carried by pigeons, fungi are rarely investigated except for Cryptococcus that is well-known for fatal meningitis; it causes on

Copyright: Syakalima, et al. Open Access. This article is distributed under the terms of the Creative Commons Attribution 4.0 International License (http://creativecommons.org/licenses/ by/4.0/), which permits unrestricted use, distribution, and reproduction in any medium, provided you give appropriate credit to the original author(s) and the source, provide a link to the Creative Commons license, and indicate if changes were made. The Creative Commons Public Domain Dedication waiver (http:// creativecommons.org/publicdomain/zero/1.0/) applies to the data made available in this article, unless otherwise stated. immunosuppressed humans such as the old, sick, and HIV-positive patients. Other emerging opportunistic fungal infections from genera such as Aspergillus, Penicillium, Mucor, Rhizopus, Paecilomyces, Fusarium, Alternaria, and Cladosporium are gaining recognition and have been implicated in a variety of infections in humans [3-8]. Pigeons are known to carry fungi that are pathogenic to human such as those that cause Cryptococcal meningitis, because of this there is interest in knowing the pathogenic role of other fungi that may be found in pigeons.

Feral pigeons are an ever-increasing presence in the North West Province of South Africa; however, few investigations exist on their probable public health risk. This study investigated fungi in feces of pigeons collected around Mafikeng, the capital city of the North West Province of South Africa with special emphasis on fungi that are known to be opportunistic pathogens to humans.

\section{Materials and Methods}

\section{Ethical approval}

The fecal samples were collected where the pigeons nest. Therefore, the present study did not engage any invasive procedure and therefore, ethical approval was not required. Furthermore, the pigeons are not an endangered species and their feces are routinely cleaned and disposed off as a nuisance. 


\section{Study site, sample collection, and processing}

Fresh fecal samples of pigeons (Columba livia) were collected early in the morning from buildings around Mafikeng where the pigeons nest. Mafikeng is the capital of the North West Province of South Africa and is the hub of major agricultural activities. There was no requirement for permission to sample the feces because they were normally regarded as a nuisance and dirt in the area and the birds are not endangered species.

The freshly dropped feces were identified and a scoop of more than a gram of feces was done to the top layer of feces using sterile spatulas to minimize contamination. After collection, the feces were placed in screw-capped sterile sampling tubes and placed in a cooler box with ice packs for transportation to the laboratory at the North-West University, Mafikeng Campus.

At the laboratory, the fecal samples $(1.0 \mathrm{~g})$ were suspended in a $10.0 \mathrm{ml}$ volume of sterilized phosphate-buffered saline $\mathrm{pH}$ 7.2. They were left in this solution overnight at $48^{\circ} \mathrm{C}$. The next day $0.1 \mathrm{ml}$ aliquot of each dilution was spread uniformly on Sabouraud's dextrose agar (Sigma-Aldrich, South Africa) and the plates were incubated at $48^{\circ} \mathrm{C}$ for 2 weeks observing them for any fungal growth from day 2 .

When the appearance of colonies was observed, the characteristics of these colonies were noted and some of the representative types of colonies were further subcultured and incubated in a similar manner above to get pure colonies. The pure colonies were then picked up and used for DNA extraction.

\section{Extraction of genomic DNA}

For DNA genomic extraction, a single pure colony from the subcultures was picked up and subjected to a DNA extraction protocol of the QuickDNA $^{\mathrm{Tм}} \quad$ Fungal/Bacterial Miniprep Kit (Zymo Genomic DNA-Tissue MiniPrep, USA). The manufacturer's recommendations were strictly adhered to. The DNA concentration was determined using NanoDrop ND-1000 ultraviolet (UV) spectrophotometer (Thermo-Fisher Scientific Inc., USA) with a wavelength of $260 \mathrm{~nm}$. The resultant DNA eluted was then kept at $-80^{\circ} \mathrm{C}$ until polymerase chain reaction (PCR) was performed.

\section{DNA amplification}

The fungi isolates were identified by amplification of the internal transcribed spacer (ITS) gene. The ITS gene fragment is specific to fungi and most fungi yield products from 600 to $650 \mathrm{bp}$ [9]. The primer set used to amplify the ITS region were ITS1 (5'-TCC GTA GGT GAA CCT GC GG-3') and ITS4 (R-TCC TCC GCT TAT TGA TAT GC-3'). The PCR was done in a total volume of $25 \mu \mathrm{L}$ of reaction mixture containing $1 \mu \mathrm{L}$ of each primer pair $(10 \mathrm{pM}), 1$ unit of Taq polymerase, $0.25 \mathrm{mM}$ dNTP, $10 \mathrm{mM}$ Tris- $\mathrm{HCl}$ (pH 9.0), $30 \mathrm{mM} \mathrm{KCl}, 1.5 \mathrm{mM} \mathrm{MgCl}_{2}$, and $1 \mu \mathrm{L}$ of DNA template $(1 \mu \mathrm{g} / \mu \mathrm{L})$. PCR amplification was performed with a DNA thermal cycler (model - Bio-RAD C1000 Touch TM Thermal Cycler) using the following conditions: Initial denaturation at $94^{\circ} \mathrm{C}$ for $5 \mathrm{~min} ; 35$ cycles of $94^{\circ} \mathrm{C}$ for $1 \mathrm{~min}, 53^{\circ} \mathrm{C}$ for $1 \mathrm{~min}$, and $72^{\circ} \mathrm{C}$ for $90 \mathrm{~s}$, and a final extension at $72^{\circ} \mathrm{C}$.

\section{Electrophoresis of PCR products}

The PCR products were separated by electrophoresis on $1.5 \%(\mathrm{w} / \mathrm{v})$ agarose gel on a horizontal BioRad equipment system (model - BCMSCHOICE; Biocom, UK). The gel was run for $60 \mathrm{~min}$ at $80 \mathrm{~V}$ and $250 \mathrm{MA}$ using $1 \times$ TAE buffer (40 mM Tris, $1 \mathrm{mM}$ EDTA, and $40 \mathrm{mM}$ glacial acetic acid, pH 8.0). Each gel contained a 1000 bp DNA molecular weight marker (Fermentas, USA). The gel was stained in ethidium bromide $(0.1 \mu \mathrm{g} / \mathrm{ml})$ and amplicons were visualized under UV light at $420 \mathrm{~nm}$ wavelength. The PCR product for sequencing was purified at Inqaba Biotech Laboratories in Pretoria, South Africa.

The resulting sequences were compared with reference data available in the GenBank database using BLAST (www.ncbi.nlm.nih.gov/BLAST) from the National Centre for Biotechnology Information (NCBI) to determine species identification with high similarity [10].

\section{Phylogenetic relationships}

The evolutionary history was inferred using the maximum likelihood method based on the JukesCantor model [11]. Initial tree(s) for the heuristic search were obtained automatically by applying neighbor-joining and BioNJ algorithms to a matrix of pairwise distances estimated using the maximum composite likelihood approach and then selecting the topology with superior log-likelihood value. The tree was drawn to scale, with branch lengths measured in the number of substitutions per site. The analysis involved 35 nucleotide sequences. Codon positions included were $1^{\text {st }}+2^{\text {nd }}+3^{\text {rd }}+$ Non-coding. All positions containing gaps and missing data were eliminated. There were a total of 490 positions in the final dataset. Evolutionary analyses were conducted in MEGA7 software (Pennsylvania University, USA) [12].

\section{Results}

For a total of 30 samples that were cultured on Sabouraud's dextrose agar, 20 (66.6\%) had colonies that gave positive reactions to the ITS primers with resulting bands on the gel that fell within the 600$650 \mathrm{bp}$ range (Figure-1).

After sequencing and blasting on the NCBI database, the identities of the fungi were known as shown below together with their percentages similarities and accession numbers. The sequences obtained from the current study have been submitted to the GenBank database and assigned accession numbers are shown in Table-1.

The tree with the highest log likelihood is shown in Figure-2 and represents similar fungi isolated in studies elsewhere, especially from infections. The 
percentage of likelihood, in which the associated taxa clustered together, is shown next to the branches.

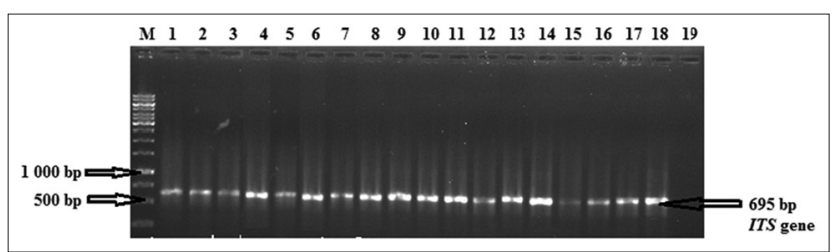

Figure-1: Electrophoresis in a $1.5 \%$ agarose gel of polymerase chain reaction amplified internal transcribed spacer (ITS) gene. Lane M: Molecular weight marker (1 kb); Lane 1-18 (ITS gene fragments from DNA extracted from pigeons feces), Line 19: Negative control.

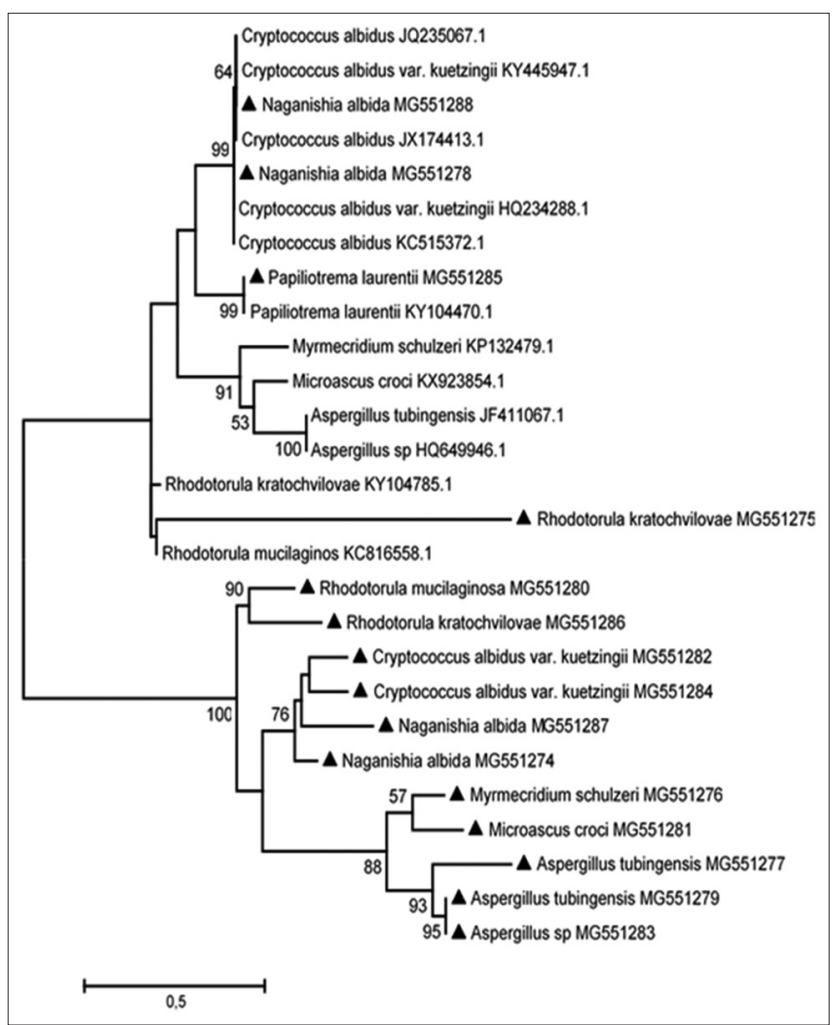

Figure-2: The evolutionary history of isolated fungi using the maximum likelihood method.

\section{Discussion}

This study isolated and characterized a number of fungi groups that are known to pose significant opportunistic risks. These included Aspergillus, Cryptococcus, Fusarium, and Rhodotorula genera. The phylogenetic tree indicates some strains similar to the ones in this study that was isolated elsewhere and was involved in various opportunistic infections.

Aspergillus species are known to cause significant morbidity and mortality in humans. They are associated with a number of clinical forms such as disseminated infections, respiratory infections, subcutaneous infections, rhinocerebral infections, skin and nail infections, ear infections, and keratitis [12]. Aspergillus tubingensis was identified in the pigeon feces in this study and is a known opportunistic pathogen. A. tubingensis is most often involved in food spoilage of fruits and wheat, and industrial fermentation; however, it is also a rare agent of opportunistic infections such as corneal infections [13] as well as infections of maxillary bone following a tooth extraction [14]. Its presence in pigeon feces and contamination of the human environment should, therefore, raise public health concerns, especially for the elderly and immunosuppressed.

A number of Cryptococcus species were also isolated from these fecal samples and this genus, in general, is regarded a public health risk. Under this genus, Cryptococcus neoformans is the major human and animal pathogen responsible for serious disease in immunosuppressed patients. C. neoformans was, however, not isolated during this study, but two Cryptococcus species of opportunistic importance, Cryptococcus albidus and Cryptococcus randhawai were detected. Of the two, C. albidus is of significance because it has also been found to occasionally cause moderate-to-severe meningitis, in human patients with compromised immunity due to HIV infection, cancer chemotherapy, metabolic immunosuppression, etc. $[15,16]$.

Fusarium spp. are usually important for their role in the production of mycotoxins and only $F$. solani

Table-1: All the fungi types that were identified from the samples collected.

\begin{tabular}{|c|c|c|c|c|}
\hline Samples ID & Reference from NCBI database & $\begin{array}{c}\text { Percentage } \\
\text { similarity }(\%)\end{array}$ & $\begin{array}{c}\text { Accession number in } \\
\text { GenBank (PCR) }\end{array}$ & $\begin{array}{c}\text { Assigned } \\
\text { accession numbers }\end{array}$ \\
\hline NWU 1 & Naganishia albida & 99 & KY744108.1 & MG551274 \\
\hline NWU 2 & Rhodotorula kratochvilovae & 99 & KY104785.1 & MG551275 \\
\hline NWU 3 & Myrmecridium schulzeri & 99 & KP132479.1 & MG551276 \\
\hline NWU 4 & Aspergillus tubingensis & 100 & JF411067.1 & MG551277 \\
\hline NWU 5 & Naganishia albida & 99 & KC515372.1 & MG551278 \\
\hline NWU 7 & Aspergillus tubingensis & 100 & JF411067.1 & MG551279 \\
\hline NWU 8 & Rhodotorula mucilaginosa & 100 & KC816558.1 & MG551280 \\
\hline NWU 9 & Microascus croci & 99 & KX923854.1 & MG551281 \\
\hline NWU 10 & Cryptococcus albidus & 99 & KY445947.1 & MG551282 \\
\hline NWU 11 & Aspergillus sp. & 100 & HQ649946.1 & MG551283 \\
\hline NWU 12 & Cryptococcus albidus & 100 & HQ234288.1 & MG551284 \\
\hline NWU 13 & Papiliotrema laurentii & 100 & KY104470.1 & MG551285 \\
\hline NWU 14 & Rhodotorula kratochvilovae & 100 & KY104785.1 & MG551286 \\
\hline NWU 16 & Naganishia albida & 99 & MG250421.1 & MG551287 \\
\hline NWU 17 & Naganishia albida & 100 & KU883298.1 & MG551288 \\
\hline
\end{tabular}

$\mathrm{PCR}=$ Polymerase chain reaction, $\mathrm{NCBI}=$ National Center for Biotechnology Information 
and $F$. oxysporum have been implicated in human diseases such as disseminated infections, keratitis, skin, and nail infections [12]. F. polyphialidicum, which was detected in this study, is only known as a plant pathogen [17].

Rhodotorula species have emerged as opportunistic pathogens that have the ability to colonize and infect susceptible patients. Among the Rhodotorula species, Rhodotorula mucilaginosa and Rhodotorula kratochvilovae were detected in our study. Of the two, only $R$. mucilaginosa is commonly isolated from foods and beverages and is a known opportunistic pathogen causing Rhodotorula fungemia associated with central catheters in patients with hematologic malignancies [18].

Apart from the fungi mentioned above, the other fungi detected in our study, namely, Graphium dubautiae, Myrmecridium schulzeri, Naganishia albida, Paecilomyces lilacinus, and Zygopleurage zygospora were not found to be of any human health significance despite an extensive literature search. However, further investigations may be required to completely establish a low risk.

\section{Conclusion}

This study found a number of opportunistic fungi which should arouse public health interest as humans share a contaminated environment with pigeons. Fungi that are opportunistic to the immunosuppressed and the old are especially of interest and should stimulate interest of stakeholders. Further and more specific studies are therefore recommended in order to establish the full extent of the risks the pigeons are responsible for.

\section{Authors' Contributions}

TR performed the experiments and wrote the first draft, NL provided the analysis tools and analyzed the data, and MS conceived and designed the experiments, provided reagents, materials, and wrote the final paper. All authors read and approved the final manuscript.

\section{Acknowledgements}

This work was supported by the funds from Faculty of Natural and Agricultural Sciences and the Department of Animal Health, North-West University, Mafikeng Campus, South Africa.

\section{Competing Interests} interests.

The authors declare that they have no competing

\section{Publisher's Note}

Veterinary World remains neutral with regard to jurisdictional claims in published map and institutional affiliation.

\section{References}

1. Chae, H., Park, G., Kim, S., Jo, H., Kim, J., Jeoung, H., An, D., Kim, N., Shin, B. and Kang, Y. (2012) Rapid direct identification of Cryptococcus neoformans from pigeon droppings by nested PCR using CNLAC1 gene. Poult. Sci., 91(8): 1983-1989.

2. Tanaka, C., Miyazawa, T., Watarai, M. and Ishiguro, N. (2005) Bacteriological survey of feces from feral pigeons in Japan. J. Vet. Med. Sci., 67(9): 951-953.

3. Shah, S., Birnbaum, B. and Jacobs, J. (2001) Disseminated aspergillosis inciting intestinal ischemia and obstruction. Br. J. Radiol., 74(888): 1145-1147.

4. Dannaoui, E. and Garcia-Hermoso, D. (2007) The Zygomycetes. New Insights in Medical Mycology. Springer, New York. p159-183.

5. Nucci, M. and Anaissie, E. (2007) Fusarium infections in immunocompromised patients. Clin. Microbiol. Rev., 20(4): 695-704

6. Courville, P., Favennec, L., Viacroze, C., Barrel, A., Young, P., Abboud, P., Thomine, E., Metayer, J. and Nouvet, G. (2002) Co-existent cutaneous cryptococcosis of the forearm and cutaneous alternariosis of the leg in patient with metastatic thymoma. J. Cutan. Pathol., 29(1): 55-58.

7. Aguilar, C., Pujol, I., Sala, J. and Guarro, J. (1998) Antifungal susceptibilities of Paecilomyces species. Antimicrob. Agents Chemother., 42(7): 1601-1604.

8. Odds, F.C. (1991) Potential for penetration of passive barriers to fungal invasion in humans. In: The Fungal Spore and Disease Initiation in Plants and Animals. Springer, New York. p287-295.

9. Mitchell, T.G., Freedman, E.Z., White, T.J. and Taylor, J.W. (1994) Unique oligonucleotide primers in PCR for identification of Cryptococcus neoformans. J. Clin. Microbiol., 32(1): 253-255.

10. Syakalima, M., Munyeme, M. and Yasuda, J. (2016) Cytochrome $\mathrm{c}$ oxidase sequences of Zambian wildlife helps to identify species of origin of meat. Int. J. Zool., 2016(5): 1-6.

11. Jukes, T.H., Cantor, C.R. and Munro, H. (1969) Evolution of protein molecules. In: Mammalian Protein Metabolism. Vol. 3. Academic Press, New York. p21-132.

12. Rodrigues, A.M., de Hoog, G.S., de Cássia Pires, D., Brihante, R.S.N., da Costa Sidrim, J.J., Gadelha, M.F., Colombo, A.L. and de Camargo, Z.P. (2014) Genetic diversity and antifungal susceptibility profiles in causative agents of sporotrichosis. BMC Infect. Dis., 14(1): 219.

13. Kredics, L., Varga, J., Kocsubé, S., Rajaraman, R., Raghavan, A., Dóczi, I., Bhaskar, M., Németh, T.M., Antal, Z. and Venkatapathy, N. (2009) Infectious keratitis caused by Aspergillus tubingensis. Cornea, 28(8): 951-954.

14. Bathoorn, E., Salazar, N.E., Sepehrkhouy, S., Meijer, M., de Cock, H. and Haas, P.J. (2013) Involvement of the opportunistic pathogen Aspergillus tubingensis in osteomyelitis of the maxillary bone: A case report. BMC Infect. Dis., 13(1): 59.

15. Khawcharoenporn, T., Apisarnthanarak, A. and Mundy, L.M. (2007) Non-neoformans cryptococcal infections: A systematic review. Infection, 35(2): 51-58.

16. Liu, Y., Ma, S., Wang, X., Xu, W. and Tang, J. (2014) Cryptococcus albidus encephalitis in newly diagnosed HIV-patient and literature review. Med. Mycol. Case Rep., 3(1): $8-10$

17. Steppień, Ł., Koczyk, G. and Waśkiewicz, A. (2013) Diversity of Fusarium species and mycotoxins contaminating pineapple. J. Appl. Genet., 54(3): 367-380.

18. Tuon, F.F., de Almeida, G.M.D. and Costa, S.F. (2007) Central venous catheter-associated fungemia due to Rhodotorula spp. A systematic review. Sabouraudia, 45(5): 441-447. 